\title{
Percepcja czasu - przegląd modeli teoretycznych i metod badań
}

\section{Time perception - review of theoretical models and study methods}

\author{
Anna Oroń \\ Instytut Fizjologii i Patologii Słuchu, Światowe Centrum Słuchu, Warszawa/Kajetany \\ Adres autora: Anna Oroń, Światowe Centrum Słuchu, ul. Mokra 17, Kajetany, 05-830 Nadarzyn, \\ e-mail: anna.oron@gmail.com
}

\begin{abstract}
Streszczenie
Percepcja czasu jest zagadnieniem badanym od ponad 100 lat przez przedstawicieli wielu dyscyplin naukowych. Uważa się, że postrzeganie czasu stanowi kluczową funkcję, która leży u podłoża innych procesów poznawczych. W niniejszej pracy zostały przedstawione modele teoretyczne dotyczące percepcji czasu, począwszy od modeli opartych na badaniach behawioralnych $\mathrm{z}$ lat 60 . XX wieku, po współczesne modele oparte na badaniach neuroobrazowych. Zaprezentowane zostały niektóre nurty badawcze starające się rozwikłać zagadkę postrzegania czasu, między innymi omówiono relację pomiędzy percepcją czasu a wiekiem i mową. Opisano neurobiologiczne podłoże tego zjawiska oraz przykładowe metody badania percepcji czasu. Artykuł stanowi próbę przybliżenia czytelnikowi tematyki percepcji czasu, która mimo że nieuchwytna i ulotna stanowi fundamentalny wymiar życia ludzkiego.
\end{abstract}

Słowa kluczowe: percepcja czasu • biologiczne podłoże percepcji czasu • metody badania percepcji czasu

\begin{abstract}
The topic of time perception has been thoroughly investigated for over 100 years by researchers worldwide. It is believed that the perception of time constitutes a crucial function, which underlies other cognitive processes. In this review theoretical models have been presented, starting from those based on behavioral studies from the ' 60 s, ending with current models based on neuroimaging methods. Various studies trying to understand time perception (i.e. the relation of time perception-age-speech) as well as neurobiological basis and some methods used to study time perception were described. This review constitutes the attempt to familiarize the reader with the complex phenomenon of time perception, which despite of being intangible, is a fundamental dimension of our human life.
\end{abstract}

Key words: time perception $\bullet$ biological basis of time perception $\bullet$ methods to study timing

Czas jest fundamentalnym wymiarem życia ludzkiego. $\mathrm{Z}$ tego też powodu był jednym $\mathrm{z}$ pierwszych tematów psychologii eksperymentalnej i jest intensywnie badany od ponad 100 lat [1]. Matthews i Meck (2014) twierdzą, że czas jest podstawowym, zasadniczym czynnikiem naszego codziennego doświadczania rzeczywistości, stanowi centralny punkt właściwie wszystkich naszych czynności. Prawidłowa percepcja czasu jest niezbędna dla wykonywania wielu zadań ruchowych: od mrugnięcia powieką do gry na fortepianie [2,3]. Jednocześnie, jak podkreślają Wittmann i van Wassenhove, badania nad percepcją czasu są trudne $\mathrm{z}$ kilku powodów: przede wszystkim czas jest nieuchwytny, nie możemy go zobaczyć, usłyszeć czy poczuć, ale możemy go doświadczyć, np. czekając na kogoś [4]. Autorzy zwracają też uwagę na to, że postrzeganie czasu jest silnie uzależnione od procesów takich jak pamięć, uwaga czy emocje, które modulują percepcję czasu [4]. Czas upływa niepostrzeżenie, gdy doświadczamy czegoś przyjemnego, ale wydaje się dłużyć, gdy doświadczamy smutku czy przygnębienia [5]. Ze względu na złożoną naturę postrzegania czasu, zrozumienie tego zjawiska staje się multidyscyplinarnym wyzwaniem nie tylko dla dziedzin takich jak psychologia, lecz także neurobiologia, biologia molekularna i komórkowa, genetyka, neuroinformatyka i inne [6]. Block i Grondin [7] udowadniają, że pomimo złożoności tej tematyki jest ona szeroko studiowana i eksplorowana na całym świecie. Celem niniejszego opracowania jest zaprezentowanie aktualnej wiedzy na temat percepcji czasu, modeli teoretycznych wyjaśniających to zjawisko, przykładowych metod badania oraz biologicznego podłoża zjawiska postrzegania czasu. 


\section{Przegląd modeli teoretycznych dotyczących percepcji czasu}

Czasowe opracowywanie informacji może być rozpatrywane na wielu różnych poziomach: od milisekund po lata. Istnieje wiele psychologicznych, psychofizycznych czy neuropsychologicznych dowodów na to, że ludzkie zachowanie ma pewną charakterystykę czasową. Czasowe opracowywanie informacji stanowi podstawę, czy też główny komponent, wielu procesów poznawczych, takich jak percepcja, pamięć, uwaga, język czy aktywność ruchowa [8].

Wraz z rozpoczęciem badań nad percepcją czasu, badacze starali się wyjaśnić, w jaki sposób przetwarzamy czas, tworząc teorie i modele teoretyczne. Do czasów obecnych opracowano wiele modeli teoretycznych, które starają się rozwikłać ten problem. Przez ostatnie dziesięciolecia percepcja czasu opisywana była między innymi w nurcie modeli hierarchicznych, które zakładały, że doświadczenie upływającego czasu można rozpatrywać na różnych poziomach czasowego przetwarzania informacji [9-12]. Poniżej zaprezentowane zostały modele stworzone przez Fraisse’a i bardziej współczesny model hierarchiczny Pöppela, $\mathrm{w}$ dalszej części omówiono modele zegarowe oraz modele dynamicznych sieci neuronalnych.

Już w latach 60. XX w. Fraisse badał zjawiska czasowe. Wyodrębnił on trzy aspekty percepcji czasu: następstwo, trwanie oraz orientację w czasie $[9,10]$. Zdolność do identyfikacji porządku czasowego bodźców dotyczy następstwa. Percepcja następstwa odbywa się w przedziale czasowym poniżej $100 \mathrm{~ms}$. Percepcja trwania odnosi się do dłuższych interwałów, ale krótszych niż ok. 2 s, i dotyczy postrzegania trwałości danego zjawiska oraz interwału pomiędzy dwoma zdarzeniami. Ostatni aspekt omawiany przez Fraisse'a dotyczy orientacji w czasie, związanej ze zdolnością umiejscawiania danego zjawiska w stosunku do zmian endogennych (stan snu i czuwania) i egzogennych (rytm dobowy, pory roku) $[9,10]$.

Koncepcja Fraisse’a została rozbudowana w latach późniejszych przez Pöppela, który zaproponował hierarchiczny model percepcji czasu [11-14]. W swoim modelu rozdziela on czas obiektywny, pojmowany w sensie fizycznym, płynący niezależnie od zachodzących zdarzeń, od czasu subiektywnego, który jest indywidualnie odbierany przez każdego człowieka i determinowany jest mechanizmami mózgowymi. Pöppel wyróżnił kilka zakresów czasowego opracowywania informacji, które są ze sobą związane w sposób hierarchiczny, tzn. zjawisko z niższego poziomu jest podstawą zaistnienia zjawiska $\mathrm{z}$ wyższego szczebla. Wymienia on: jednoczesność, niejednoczesność, następstwo, teraźniejszość i trwanie [12,15-18]. Każdy z poziomów, zdaniem Pöppela, jest związany z działaniem określonego mechanizmu neuronalnego, operującego w specyficznym oknie czasowym $[19,20]$.

Najbardziej podstawowym zjawiskiem w modelu Pöppela jest percepcja jednoczesności vs. niejednoczesności, a zakłada ona, że jeśli pomiędzy dwoma zdarzeniami istnieje bardzo krótki odstęp czasu, to zostaną one spostrzeżone jako występujące jednocześnie. Oddzielenie bodźców odpowiednio długim interwałem czasowym (różnym w zależności od modalności) umożliwia percepcję dwóch bodźców, np. dla modalności słuchowej będzie to odstęp wynoszący ok. 2-5 ms, a dla modalności wzrokowej: $20-30 \mathrm{~ms}[13,14]$.

Percepcja czasowego następstwa dwóch bodźców stanowi kolejny poziom w hierarchicznym modelu percepcji czasu Pöppela [12]. Dotyczy ona określenia kolejności występowania dwóch zdarzeń, a nie jedynie spostrzeżenia, czy występują one jednocześnie czy też niejednocześnie. Istnieje wiele badań, które dowodzą, że aby prawidłowo podać kolejność dwóch następujących po sobie zdarzeń, przerwa pomiędzy nimi musi wynosić ok. $30 \mathrm{~ms}$. (tzw. próg postrzegania kolejności). Wartość ta jest zbliżona dla różnych modalności. W zależności od stosowanych metod, próg ten może się wahać od ok. 20 do 60 ms [21-23]. Istnieje wiele dowodów eksperymentalnych, które podkreślają istotność tego krótkiego interwału dla przebiegu wielu funkcji poznawczych (przykłady w dalszej części artykułu), jak również uwydatniających neuronalne podłoże tego zjawiska.

Zjawisko teraźniejszości stanowi kolejny poziom w modelu percepcji czasu Pöppela. Dotyczy ono spostrzegania informacji w zakresie 2-3 sekund, co związane jest ściśle $\mathrm{z}$ działaniem tzw. mechanizmu integracyjnego, łączącego następujące po sobie porcje nowych informacji w większe fragmenty. W ten sposób tworzy się subiektywne poczucie teraźniejszości, które umożliwia utrzymanie określonej porcji informacji w pamięci $[11,14,15,24]$. Istnieje szereg paradygmatów eksperymentalnych, które skupiają się na badaniu tego zjawiska. Niektóre z nich zostały omówione poniżej.

Percepcja trwania wydarzeń w czasie i odczuwanie ciągłości upływu czasu dotyczą ostatniego poziomu percepcji czasu w modelu Pöppela, a mianowicie - przeżywania trwania [15]. Informacje zespolone ze sobą dzięki mechanizmowi integracyjnemu zawierają powiązane ze sobą treści, które człowiek łączy i w ten sposób odczuwa trwanie w czasie [15].

Model Pöppela nie uwzględnia jednego ważnego poziomu czasowego przetwarzania informacji, który dotyczy zakresu kilkuset milisekund. Poziom ten związany jest $\mathrm{z}$ sekwencyjnymi procesami ruchowymi [25], a przykładowe paradygmaty eksperymentalne stosowane do badania tego zakresu zostały opisane poniżej.

\section{Biologiczne podłoże percepcji czasu}

Wyzwaniem dla badaczy percepcji czasu jest poszukiwanie jej neuronalnych i anatomicznych korelatów. Jak piszą Matthews i Meck, nie posiadamy jednego organu sensorycznego odpowiedzialnego za odbieranie informacji na temat upływającego czasu i przesyłanie tych informacji do mózgu [1]. Autorzy twierdzą, że wszystkie układy sensoryczne wspomagają i wspierają postrzeganie czasu, ale to, w jaki sposób do tego dochodzi, pozostaje nadal kwestią niewyjaśnioną [1]. Dodatkowym problemem w badaniach nad percepcją czasu jest to, że czas przetwarzany jest jednocześnie na różnych skalach czasowych i angażuje różne mechanizmy mózgowe w tym samym czasie, co znacznie utrudnia poszukiwanie neuronalnych korelatów percepcji czasu. W związku z tym wiele pytań dotyczących postrzegania czasu pozostaje nadal bez odpowiedzi. Badacze 
spierają się na temat relacji pomiędzy czasem fizycznym a subiektywnie odczuwanym upływem czasu, nad ich liniową czy też nieliniową zależnością. Podobnie naukowcy nie znaleźli porozumienia w kwestii tego, czy percepcja czasu bazuje na procesach scentralizowanych czy lokalnych. Inaczej mówiąc, czy istnieje jeden scentralizowany mechanizm mózgowy, który reguluje przepływ czasu niezależnie od skali (milisekundy - minuty), czy może przetwarzanie czasu odbywa się w lokalnych sieciach neuronalnych, zmieniających się w zależności od specyficznego bodźca. W odniesieniu do pierwszego podejścia rozwinęły się modele tzw. zegara wewnętrznego (ang. internal clock), natomiast drugie podejście bazuje na zjawisku pobudzanych sieci neuronalnych (ang. state dependent networks, SDN).

Modele „zegara wewnętrznego” pośredniczącego w percepcji czasu powstały w latach 60 . Zakładają one, że w procesie opracowywania czasowych aspektów informacji bierze udział scentralizowany mechanizm czasowy, zwany zegarem wewnętrznym, który za pomocą generatora rytmu emituje impulsy (wewnętrzne jednostki czasu) w określonym tempie [26]. Impulsy te rejestrowane są przez licznik, zwany też akumulatorem [27-30]. Koncepcja zegara zakłada, że upływ czasu jest liczony w jednostkach, które mogą być łączone lub porównywane linearnie [26]. Modele zegarowe były bardzo popularne w badaniach psychofizycznych, polegających np. na szacowaniu długości bodźców. Rammsayer i Brandler rozważali, czy wykonanie różnych zadań czasowych może bazować na jednym zegarze wewnętrznym [31]. Przeprowadzili eksperymenty mające na celu sprawdzenie różnych wymiarów czasowego przetwarzania informacji. Autorzy przebadali grupę 120 osób, które wykonywały 8 zadań dotyczących czasowego przetwarzania informacji. Wyniki sugerowały istnienie jednego generatora rytmu, który był zaangażowany w szacowanie długości bodźców i określanie ich kolejności. Autorzy twierdzili natomiast, że percepcja rytmu, jednoczesności/niejednoczesności jest kontrolowana przez inny proces, związany z danym zadaniem [31]. Wielu badaczy skupiało się na badaniu mechanizmów czasowych w różnych modalnościach zmysłowych, udowadniając, iż różnicowanie trwania bodźców (ang. temporal discrimination) zmienia się w zależności od modalności i cech bodźców [32,33]. Stauffer i wsp. podkreślili wyższą wrażliwość na różnicowanie bodźców systemu słuchowego niż systemu wzrokowego niezależnie od typu zadania i tym samym istnienie niezależnych systemów przetwarzających informacje różnej modalności, nad którymi dominuje system niezależny od modalności [34].

Karmarkar i Buonomano stwierdzili natomiast, że badania neuroobrazowe nie potwierdzają istnienia jednego zegara wewnętrznego [26]. Wittmann i von Wassenhove podkreślili z kolei, że model zegarowy doskonale odzwierciedla jedynie biologicznie uwarunkowany zegar dobowy, który reguluje rytmy dobowe snu i czuwania z periodycznością ok. 24 godzin $[4,6]$. Autorzy podsumowali, że pomimo wielu wysiłków nie odnaleziono zegara wewnętrznego, który by przetwarzał czas $\mathrm{w}$ przedziale milisekund, sekund czy minut [4].

Od szeregu lat prowadzone są badania wskazujące, że mózg reprezentuje czas w sposób rozproszony, aktywując wiele populacji neuronów [35]. Zaproponowano kilka nowych modeli, wyjaśniających kodowanie czasu przez układ nerwowy, m.in. model wzrastającej aktywności neuronalnej (ang. climbing firing rate model) i model wielu generatorów oscylacji (ang. the multiple oscillator model). Pierwszy opisuje wzrost aktywności neuronalnej w określonych obszarach mózgu, m.in. w korze przedczołowej i innych strukturach związanych $\mathrm{z}$ antycypacją nadchodzących bodźców [36,37]. Drugi model wskazuje na to, że czas może być kodowany w wielu oscylacjach neuronów o różnej bazowej częstotliwości [38,39]. Karmarkar i Buonomano podali alternatywny model kodowania czasu, który jest oparty na specyficznym stanie sieci neuronalnej (ang. state dependent networks, SDN) [26]. Według tego modelu, w oknie czasowym kilkuset milisekund, czas może być reprezentowany przez specyficzny stan wzbudzenia sieci neuronalnej. W modelu tym zakłada się, że istotne jest nie tylko to, które neurony są wzbudzane, lecz także potencjał spoczynkowy błony komórkowej każdego neuronu sieci i siła połączeń synaptycznych $\mathrm{w}$ każdym punkcie czasu. Jest to ważne dlatego, że nawet przy aktualnym braku bodźca historia ostatniej stymulacji pozostaje zakodowana w sieci neuronalnej $[3,26]$. Brak zgody wśród naukowców w kwestii sposobu przetwarzania czasu przez układ nerwowy ma swoje odzwierciedlenie w obecnych próbach łączenia różnych modeli, opartych zarówno na zegarach wewnętrznych, jak i na sieciach neuronów (porównaj [40]). Dodatkowo, naukowcy zaczynają odchodzić od badania tylko i wyłącznie percepcji czasu, ale zaczynają badać to zjawisko łącznie $\mathrm{z}$ innymi funkcjami poznawczymi, które wydają się wpływać na postrzeganie czasu i być nierozłącznym elementem tego procesu. W najnowszym opracowaniu Gu i wsp. proponują wspólny model czasowego przetwarzania informacji oraz pamięci roboczej (ang. a coupled excitatory - inhibitory oscillation model), zakładający, że oba te procesy zakorzenione są w tych samych oscylacjach neuronalnych, obejmujących obwody: kora przedczołowa - prążkowie hipokamp. Autorzy argumentują słuszność swojego modelu zaburzeniami wspomnianych funkcji u pacjentów psychiatrycznych oraz neurologicznych [41].

Wraz z pojawieniem się nowoczesnych technologii umożliwiających obrazowanie funkcji mózgu, naukowcy podjęli próby zbadania anatomicznych korelatów czasowego przetwarzania informacji i znalezienia lokalizacji mózgowej reprezentacji czasu [42-44]. Coull i wsp. w swojej przeglądowej pracy dotyczącej neuroanatomicznych i neurochemicznych substratów czasu wymienili szereg struktur kluczowych dla percepcji czasu w różnych zakresach czasowych [45]. Przykładowo, móżdżek wymieniany jest jako struktura zaangażowana w szacowanie krótkich interwałów (poniżej jednej sekundy). Kora przedczołowa $\mathrm{z}$ kolei uważana jest za obszar kluczowy w przetwarzaniu interwałów o długości powyżej jednej sekundy, czemu towarzyszy zaangażowanie procesów uwagowych i pamięci roboczej. Wyniki te zostały potwierdzone w badaniach przy użyciu przezczaszkowej stymulacji magnetycznej: stymulacja móżdżku osłabiała szacowanie czasu na poziomie milisekund, natomiast stymulacja prawej kory przedczołowej osłabiała percepcję ponadsekundowych interwałów [za: 45]. Meck i wsp. zwrócili uwagę na ważną rolę struktur korowych i jąder podstawy w wykonywaniu zadań związanych z różnicowaniem długości bodźców w zakresie kilkuset milisekund i kilku sekund. Podkreślili nadrzędną rolę grzbietowej części prążkowia w procesach czasowego przetwarzania 
informacji [46]. Również wielu innych autorów zwróciło uwagę na wiodącą rolę jąder podstawy w percepcji czasu, np. Livesey i wsp. wykazali między innymi aktywację prążkowia, ale też móżdżku, kory przedczołowej i dolnego płacika ciemieniowego w zadaniu polegającym na różnicowaniu długości bodźców [47]. O zaangażowaniu prążkowia (dokładniej: prawego jądra ogoniastego) w szacowanie bodźców o długości: 1300 ms i 450 ms pisali też Pouthas i wsp. [48]. Nenadic i wsp. podkreślili rolę jąder podstawy, a szczególnie prawej skorupy, w zadaniu polegającym na szacowania długości tonów (1000-1400ms) w porównaniu z zadaniami różnicowania częstotliwości, uznając m.in. prawą skorupę za strukturę centralną dla czasowego opracowywania informacji [49]. Natomiast Jones i Jahanshahi podkreślili rolę substancji czarnej w czasowym opracowywaniu informacji [50]. Powyższe dane sugerują, że szereg struktur mózgowych jest zaangażowanych w przetwarzanie czasu. Udział konkretnej struktury zależy od zakresu czasowego, jaki w danym momencie analizowany jest przez układ nerwowy, jak również od zastosowanych bodźców.

\section{Metody badania percepcji czasu}

Ze względu na złożoność pojęcia, jakim jest percepcja czasu, do badania poszczególnych jej zakresów czasowych stosuje się zróżnicowane metody. Inaczej bowiem bada się postrzeganie czasu na poziomie milisekund, a inaczej na poziomie sekund. Co więcej, obecnie dostęp do nowych technologii umożliwia badanie percepcji czasu nie tylko na poziomie behawioralnym, lecz także $z$ użyciem metod elektrofizjologicznych czy neuroobrazowych, takich jak funkcjonalny rezonans magnetyczny (np. $[42,51])$. Poniżej zaprezentowano wybrane metody do badania czasowego opracowywania informacji na różnych poziomach, zwracając jednocześnie uwagę na zróżnicowaną tematykę prowadzonych badań.

\section{Badanie czasowego następstwa dwóch bodźców w zakresie kilkudziesięciu milisekund}

Według modeli klasycznych percepcja czasu oparta jest na dwóch zjawiskach: następstwa zdarzeń oraz postrzegania długości $[23,30]$. Percepcja następstwa zdarzeń odnosi się do postrzegania kolejności dwóch bodźców, które oddzielone są od siebie krótką przerwą, tak aby określić ich kolejność: „przed - po”, natomiast postrzeganie długości odnosi się do minimalnej różnicy w długości dwóch bodźców potrzebnej, aby prawidłowo określić ich stosunek: „długi - krótki” [52]. Jak wspominano wyżej, u ludzi próg postrzegania kolejności bodźców waha się pomiędzy 20 a 60 ms, tyle wynosi minimalna przerwa pomiędzy bodźcami potrzebna do prawidłowego wskazania ich kolejności (m.in. [21-23]).

W literaturze przedmiotu wyróżnia się szereg metod służących badaniu następstwa czasowego dwóch bodźców. Poniżej przedstawiono wybrane metody wykorzystujące bodźce werbalne i niewerbalne.

Szymaszek i wsp. badali zmiany w percepcji czasu w zależności od wieku i poziomu funkcjonowania poznawczego osób badanych [22]. Autorzy stosowali dwie metody do oszacowania następstwa zdarzeń: postrzeganie dwóch $1 \mathrm{~ms}$ dźwięków (klików; Zadanie 1) lub dwóch 10 ms tonów o częstotliwości $400 \mathrm{~Hz}$ (niski ton) i $3000 \mathrm{~Hz}$ (wysoki ton; Zadanie 2). Przerwa między bodźcami zmieniała się w zależności od odpowiedzi osoby badanej. Kliki były prezentowane osobom badanym rozdzielnousznie, natomiast tony - obuusznie. Osoby badane miały za zadanie wskazać kolejność usłyszanych dźwięków: „prawy - lewy” albo „lewy prawy” w przypadku Zadania 1 oraz „niski - wysoki” albo „wysoki - niski” w przypadku Zadania 2. Przerwa pomiędzy bodźcami (ang. Inter Stimulus Interval, ISI) zmieniała się w granicach 1-200 ms. Program komputerowy ustalał próg, przy którym osoba badana potrafiła podać prawidłową kolejność usłyszanych dźwięków. Podobne metody do oceny czasowego następstwa dwóch bodźców stosowane były w innych badaniach [por. 53,54]. Omawiane badania wykazały, że percepcja czasu na poziomie kilkudziesięciu milisekund pogarsza się z wiekiem osób badanych, tj. osoby starsze potrzebowały więcej czasu, aby prawidłowo podać kolejność dwóch bodźców. Autorzy wyjaśnili swoje wyniki między innymi malejącą wraz $z$ wiekiem szybkością przetwarzania informacji.

Naukowcy zwrócili również uwagę na ścisły związek czasowego przetwarzania informacji na poziomie kilkudziesięciu milisekund $\mathrm{z}$ rozumieniem mowy, szczególnie głosek zwarto-wybuchowych (takich jak: p, b, k, g), których czas trwania jest krótki i których nie można naturalnie wydłużyć [59]. Zauważono związek pomiędzy deficytami w czasowym opracowywaniu informacji w zakresie kilkudziesięciu milisekund a zaburzeniami rozumienia mowy u osób starszych [55], dzieci z dysleksją [56] czy u pacjentów $\mathrm{z}$ afazją po udarze $[57,58]$.

Fink i wsp. również badali zmiany w percepcji czasu wraz $\mathrm{z}$ wiekiem [55]. Zbadano dwie grupy osób: 1) osoby młode (20-35 lat) i 2) osoby starsze (55-70 lat) oraz użyto podobnych metod do badania czasowego przetwarzania informacji, jak autorzy wcześniej cytowanych badań [tj. 21]. Zastosowano dwa badania $\mathrm{z}$ użyciem bodźców niewerbalnych: w Zadaniu $11 \mathrm{~ms}$ kliki prezentowane były do obojga uszu oddzielnie, natomiast w Zadaniu 2 prezentowano do obojga uszu jednocześnie dwa $10 \mathrm{~ms}$ tony o częstotliwościach $800 \mathrm{~Hz}$ (niski ton) i $1200 \mathrm{~Hz}$ (wysoki ton). Zadania polegały na wskazywaniu kolejności występowania bodźców (por. powyżej). Przerwa pomiędzy bodźcami zmieniała się. Program komputerowy ustalał próg postrzegania kolejności bodźców, czyli najkrótszą przerwę między bodźcami, przy której osoba badana była w stanie podać poprawnie kolejność bodźców. Jednocześnie proszono osoby badane o wykonanie zadania językowego, polegającego na różnicowaniu głosek w słowach. Osobom badanym prezentowano po dwa obrazki i jednocześnie słowa w słuchawkach różniące się tylko jedną głoską w nagłosie, np. t-d [w cytowanych badaniach np. niem. tanken (tankować) i danken (dziękować)]. Słowa różniły się tylko jednym parametrem akustycznym, tzw. czasem rozpoczęcia dźwięczności (ang. Voice Onset Time, VOT), czyli czasem, jaki upływa pomiędzy plozją powietrza związaną z wypowiadaniem spółgłoski a wibracją strun głosowych związaną z wypowiadaniem samogłoski następującej po spółgłosce [60]. Parametr VOT różnił się w zakresie 0-90 ms. Wyniki wykazały ponownie wydłużony próg postrzegania kolejności bodźców w Zadaniu 1 i 2 u osób starszych, a większa różnica widoczna była w Zadaniu 2. Autorzy wyjaśnili, że zaburzenia w czasowym opracowywaniu informacji widoczne u seniorów, zwłaszcza 
zaobserwowane w zadaniu postrzegania kolejności tonów, mają swoje odzwierciedlenie $\mathrm{w}$ deficytach $\mathrm{w}$ przetwarzaniu cech akustycznych głosek. Zarówno głoski, jak i tony mają złożoną strukturę akustyczną, która zmienia się wraz $\mathrm{z}$ upływem czasu. W przypadku wypowiadania głosek następują szybkie ruchy formantów, czyli składowych głosek, których osoby starsze w związku ze zwolnionym przetwarzaniem czasowym nie potrafią tak skutecznie analizować. Wyniki badań wykazały, że osoby starsze gorzej różnicowały głoski dźwięczne od bezdźwięcznych (granica parametru VOT była przesunięta u osób starszych w stosunku do osób młodych) [55]. Podobne badania nad zjawiskiem VOT w grupie Polaków przeprowadziły Szeląg i Szymaszek [59].

Fogerty i wsp. również udowodnili, że wraz z wiekiem pojawiają się problemy z czasowym przetwarzaniem informacji [61]. Autorzy zbadali 186 osób: 35 osób młodych (18-31 lat) i 151 osób starszych (60-88 lat). Wszyscy uczestnicy zostali przed właściwym badaniem poddani dwóm testom: różnicowania samogłosek $\mathrm{w}$ izolacji oraz testowi inteligencji Wechslera [61]. Wykonywano 4 zadania polegające na ustalaniu czasowego następstwa samogłosek. Były to: 1) identyfikacja kolejności dwóch samogłosek prezentowanych do prawego ucha, 2) identyfikacja kolejności czterech samogłosek prezentowanych do prawego ucha, 3) identyfikacja kolejności dwóch samogłosek prezentowanych dychotomicznie (każda samogłoska prezentowana była do innego ucha), 4) identyfikacja kolejności dwóch samogłosek prezentowanych dychotomicznie (każda samogłoska prezentowana była do innego ucha, a zadanie polegało na określeniu lokalizacji pierwszego bodźca). Osoby badane udzielały odpowiedzi, naciskając na odpowiednie przyciski. Analizowaną miarą był czas od rozpoczęcia pierwszej samogłoski do rozpoczęcia drugiej samogłoski (ang. Stimulus Onset Asynchrony, SOA). Wyniki wykazały, że najkrótszy czas (SOA) w obu grupach wiekowych uzyskano w Zadaniu 1. Osoby starsze gorzej identyfikowały sekwencje samogłosek we wszystkich zadaniach w porównaniu z młodymi uczestnikami badania. Zaobserwowano również dużą zmienność wyników w obrębie grupy osób starszych. Podobne wyniki między grupami uzyskano w zadaniu polegającym na identyfikacji przestrzennej bodźców. Osoby starsze miały też większe problemy $\mathrm{z}$ wykonywaniem trudniejszych poznawczo zadań (identyfikacja następstwa 2 bodźców vs. 4 bodźców), co można wiązać z problemami w zakresie pamięci krótkotrwałej w starszym wieku. Autorzy dowiedli również, że umiejętność identyfikacji kolejności samogłosek w przedziale kilkudziesięciu milisekund jest związana $\mathrm{z}$ funkcjonowaniem poznawczym seniorów (funkcje mierzone testem WAIS), tzn. im lepsze funkcjonowanie poznawcze, tym większe umiejętności różnicowania kolejności samogłosek [61].

Powyższe przykłady badań pokazują zróżnicowane metody badań czasowego opracowywania informacji w zakresie kilkudziesięciu milisekund. Poniżej zaprezentowano wybrane metody stosowane do badania czasowego opracowywania informacji w zakresie kilkuset milisekund.

\section{Badanie percepcji czasu na poziomie kilkuset milisekund}

Wittmann i wsp. zastosowali ciekawe metody do badania percepcji czasu w zakresie kilkuset milisekund, która związana jest $\mathrm{z}$ kontrolą ruchową [25]. Autorzy przebadali grupę pacjentów neurologicznych, $\mathrm{z}$ uszkodzeniami lewej półkuli i z objawami afazji $(\mathrm{N}=42)$, z uszkodzeniami prawej półkuli ( $\mathrm{N}=26)$, z uszkodzeniami głównie podkorowymi w lewej półkuli mózgu, ale bez objawów afatycznych $(\mathrm{N}=16)$ oraz grupę osób zdrowych bez uszkodzeń ośrodkowego układu nerwowego $(\mathrm{N}=30)$. Celem badania było sprawdzenie, czy kontrola ruchowa jest związana $\mathrm{z}$ aktywnością lewej półkuli i czy istnieje dysocjacja pomiędzy tzw. tempem personalnym a tempem maksymalnym wykonywania identycznych ruchów palców. Dodatkowo autorzy chcieli zbadać związek pomiędzy czasowymi aspektami funkcji ruchowych a językiem. Zadaniem osób badanych było naciskanie palcem wskazującym na przycisk (ang. tapping) w tempie wygodnym dla osoby badanej (tzw. tempo personalne, Zadanie 1) oraz naciskanie na przycisk palcem wskazującym, ale w jak najszybszym tempie (tzw. tempo maksymalne, Zadanie 2). Osoby badane, u których nie występowały niedowłady, wykonywały oba zadania przy użyciu prawej i lewej ręki, natomiast pacjenci $\mathrm{z}$ występującymi niedowładami wykonywali zadanie jedynie przy użyciu zdrowej ręki. Badania wykazały brak istotnych różnic między grupami w naciskaniu na przycisk w tempie maksymalnym, co może sugerować, że uszkodzenia korowe i podkorowe nie wpływają na tempo wykonywania szybkich, identycznych ruchów. Różnice wyłoniły się w zadaniu badającym tempo personalne. Najwolniej naciskali na przycisk $\mathrm{w}$ tempie personalnym pacjenci $z$ lezjami lewopółkulowymi i objawami afazji. Co ciekawe, pacjenci z lezjami podkorowymi w lewej półkuli naciskali na przycisk nawet szybciej niż osoby zdrowe. Natomiast tempo wykonywania tego zadania przez pacjentów z uszkodzeniami prawej półkuli nie różniło się istotnie od wykonania zadania przez osoby z grupy kontrolnej. Badania potwierdziły związek pomiędzy czasowymi aspektami funkcji ruchowych a językiem - autorzy przypuszczają, że pacjenci $z$ afazją po uszkodzeniach lewej półkuli wykazywali zaburzenia językowe $\mathrm{z}$ powodu uszkodzeń lewopółkulowej sieci sensomotorycznej, która zaangażowana jest w czasową kontrolę funkcji ruchowych [25].

\section{Badanie percepcji czasu na poziomie kilku sekund}

Zakay i Block dokonali przeglądu metod stosowanych w badaniach nad szacowaniem długości trwania bodźca w zakresie kilku sekund [63]. Autorzy wyjaśnili, że jedną ze stosowanych metod jest prezentacja bodźca i prośba o werbalne oszacowanie jego długości. Autorzy twierdzili, że werbalne szacowanie długości bodźca jest mniej dokładne niż inne metody, jak np. (1) reprodukcja interwału, polegająca na szacowaniu długości danego bodźca standardowego i odtwarzaniu go, (2) produkcja interwału, polegająca na utworzeniu bodźca trwającego określony interwał czasu. Zakay i Block zaprezentowali też metodę estymacji czasu, polegającą na porównywaniu długości trwania dwóch bodźców [63]. Autorzy zauważyli, że skierowanie uwagi na bodziec wpływa na szacowanie długości czasu jego trwania, tzn. im bardziej skupimy się na bodźcu, tym dłuższy jest czas jego reprodukcji [63].

Metoda reprodukcji interwałów (ang. temporal reproduction), stosowana do badania zdolności przewidywania czasu trwania bodźca (ang. prospective time judgement), jest 
silnie uzależniona od funkcji poznawczych takich jak uwaga czy pamięć krótkotrwała. Według hierarchicznego modelu percepcji czasu, reprodukcja interwałów jest związana z mechanizmem czasowej integracji bodźców, który to łączy indywidualne bodźce w większe grupy w zakresie kilku sekund (por. wyżej). W badaniach eksperymentalnych wykazano, że niezależnie od modalności prezentowanego bodźca, bodźce o długości ok. 2-3 s są reprodukowane relatywnie dokładnie lub są lekko przeceniane, podczas gdy dłuższe bodźce, o długości powyżej 2-3 s (czyli niemieszczące się w granicach działania mechanizmu integracyjnego) są zazwyczaj niedocenianie [np. 15,16].

Uważa się, że mechanizm integracyjny zapewnia rytmizację mowy płynnej. Badania pokazują, że niezależnie od języka, jakim się posługujemy, mowa płynna ma specyficzną charakterystykę czasową, ograniczoną w czasie do ok. 2-3 s. Oznacza to, że po tym czasie następuje krótka pauza w mówieniu, a następnie prezentowana jest kolejna porcja informacji przez kolejne $2-3 \mathrm{~s}$. Podobna rytmizacja obserwowana jest w języku migowym czy w muzyce klasycznej. U pacjentów, u których doszło do uszkodzenia mózgu, np. w wyniku udaru, można zaobserwować objawy polegające na trudności w płynnym wypowiadaniu się, (objawy te obserwuje się u pacjentów $\mathrm{z}$ afazją Broki, która występuje po uszkodzeniu lewego płata czołowego). Długość zdania u takich pacjentów jest znacznie zredukowana. Pacjenci z implantami ślimakowymi również wykazują zaburzenia przetwarzania informacji w tym zakresie [62]. Wyniki badań Kanabus i wsp. pokazują, że użytkownicy jednokanałowych implantów ślimakowych mogą mieć problemy $z$ rozumieniem mowy na poziomie wyrazu i frazy, co może być związane z zaburzonym mechanizmem integracji informacji, działającym na poziomie kilku sekund [62]. Zbadano 12 użytkowników jednokanałowych implantów ślimakowych oraz 12 osób zdrowych, stanowiących grupę kontrolną dobraną do pacjentów pod względem wieku, płci i wykształcenia. Procedura eksperymentalna obejmowała reprodukcję bodźców słuchowych (tony $300 \mathrm{~Hz}$ ) oraz wzrokowych (zielony prostokąt pokazywany na ekranie komputera), które prezentowane były $\mathrm{z}$ różną długością (11 długości w przedziale od 1 do $9 \mathrm{~s}$ ). Badania wykazały, że w przypadku użytkowników implantów ślimakowych wzorzec odpowiedzi zależał od poziomu rozumienia mowy. Wyniki pacjentów, którzy nie wykazywali poważnych deficytów w rozumieniu mowy, nie odbiegały od wyników osób zdrowych. Pacjenci, którzy wykazywali zaburzenia rozumienia mowy, zazwyczaj przeceniali długość krótkich bodźców słuchowych (o długości 1-2,5 s). Nie zaobserwowano takiej różnicy dla modalności wzrokowej. Autorzy sugerują, że deficyty w reprodukcji krótkich interwałów mogą być jedną z przyczyn trudności $\mathrm{w}$ rozumieniu mowy u użytkowników jednokanałowych implantów ślimakowych [62].

Badania Szelag i wsp. potwierdziły związek pomiędzy funkcjami językowymi a czasowym opracowywaniem informacji w zakresie kilku sekund [64]. Autorzy zbadali
41 pacjentów z uszkodzeniami mózgu, których zakwalifikowali do 5 grup: 1) pacjenci $z$ afazją Broki, 2) pacjenci $\mathrm{z}$ afazją Wernickego lub amnestyczni, 3) pacjenci z uszkodzeniami lewej półkuli mózgu bez objawów afatycznych, 4) pacjenci z uszkodzeniami przedśrodkowego obszaru prawej półkuli mózgu, 5) pacjenci z uszkodzeniami zaśrodkowego obszaru prawej półkuli mózgu. Pacjentom prezentowano bodźce słuchowe, którymi były uderzenia metronomu generowane przez program komputerowy o 9 różnych częstotliwościach (od 1 do 5 uderzeń na sekundę). Pacjenci proszeni byli o przysłuchiwanie się tym bodźcom i akcentowanie w myślach kolejnych uderzeń w określonych odstępach - co drugiego, trzeciego, czwartego itd., tak aby utworzyć w myślach subiektywny rytm. Osoby badane miały werbalnie podawać liczbę uderzeń, które integrowały w danej jednostce czasu. Obliczano tzw. czas integracji, czyli liczbę podanych uderzeń pomnożoną przez czas pomiędzy poszczególnymi uderzeniami. W zależności od częstotliwości pacjenci integrowali inną liczbę uderzeń $\mathrm{w}$ jednostce czasu: generalnie uderzenia generowane $\mathrm{w}$ wolnym rytmie łączyli w mniejsze grupy, natomiast szybko generowane uderzenia integrowali w większe grupy. Badania wykazały, że pacjenci $z$ afazją Broki integrowali bodźce pojawiające się rzadko (niska częstotliwości uderzeń metronomu) w znacznie dłuższe interwały niż pacjenci $z$ innych grup, co więcej, integrowali bodźce pojawiające się często (wysoka częstotliwość uderzeń metronomu) w krótsze interwały niż osoby badane z pozostałych grup. Autorzy podsumowali swoje badania twierdzeniem, że trudności w integrowaniu bodźców na poziomie sekund odnajdują swoje odzwierciedlenie w problemach językowych, jakie wykazują pacjenci $z$ afazją Broki, których mowa ma charakterystyczny, telegraficzny styl i brak płynności. Autorzy sugerują, że niepłynna mowa, trudności w konstruowaniu zdań, problemy gramatyczne są związane z zaburzeniami w integracji bodźców na poziomie kilku sekund [64].

Zaprezentowany powyżej przegląd podejść teoretycznych, modeli przetwarzania czasu, jak również przykładowych metod służących do badania różnych zakresów czasowych pokazuje, jak bardzo złożonym konstruktem jest czas. $\mathrm{Z}$ pewnością przegląd ten nie wyczerpuje tematyki percepcji czasu, a jedynie uzmysławia złożoność tego zjawiska. Chociaż historia badań nad czasowym opracowywaniem informacji sięga początków psychologii eksperymentalnej, odnosi się wrażenie, że po ponad 100 latach prowadzenia badań nadal znajdujemy się w „dżungli czasu” [65], z której nie ma jednego i jasnego wyjścia. Ale pewne jest jedno, że to nieuchwytne i ulotne zjawisko jest fundamentalnym wymiarem naszego życia i wciąż będzie inspirowało naukowców na całym świecie do badań i prób zrozumienia go.

Artykuł powstał w zwiąku z realizacją projektu „Zintegrowany system narzędzi do diagnostyki i telerehabilitacji schorzeń narządów zmysłów (stuchu, wzroku, mowy, równowagi, smaku, powonienia)" INNOSENSE, wspótfinansowanego przez Narodowe Centrum Badań i Rozwoju w ramach Programu STRATEGMED. 
1. Matthews WJ, Meck WH. Time perception: the bad news and the good. Wiley Interdiscip Rev Cogn Sci, 2014; 5(4): 429-46.

2. Eagleman DM, Tse PU, Buonomano D, Nobre ACh, Holcombe AO. Time and the brain: How subjective time relates to neural time. J Neurosci, 2005; 25(45): 10369-71.

3. Mauk MD, Buonomano DV. The neural basis of temporal processing. Annu Rev Neurosci, 2004; 27: 307-40.

4. Wittmann M, van Wassenhove V. The experience of time: neural mechanisms and the interplay of emotion, cognition and embodiment. Philos Trans R Soc Lond B Biol Sci, 2009; 364: 1809-13.

5. Droit-Volet S, Meck WH. How emotions colour our perception of time. Trends Cogn Sci, 2007; 11(12): 504-13.

6. Tucci V, Buhusi CV, Gallistel R, Meck WH. Towards an integrated understanding of the biology of timing. Philos Trans R Soc Lond B Biol Sci, 2014; 369(1637): 20120470.

7. Block RA, Grondin S. Timing and time perception: A selective review and commentary on recent reviews. Front Psychol, 2014; 5: 648.

8. Szeląg E, Kanabus M, Kołodziejczyk I, Kowalska J, Szuchnik J. Individual differences in temporal information processing in humans. Neurobiol Exp (Wars), 2004; 64: 349-66.

9. Fraisse P. Psychology of time. New York: Harper \& Row; 1963.

10. Fraisse P. Perception and estimation of time. Annu Rev Psychol, 1984; 35: 1-36.

11. Pöppel E. Temporal mechanisms in perception. Int Rev Neurobiol., 1994; 37: 185-202.

12. Pöppel E. A hierarchical model of temporal perception. Trends in Cognitive Sciences, 1997; 1(2): 56-61.

13. Pöppel E. Time perception. W: Adelman G, red. Encyclopedia of Neuroscience. Boston: Birkhäuser, 1987; s. 1215-16.

14. Pöppel E. Granice świadomości. Warszawa: PIW; 1989.

15. Pöppel E. Lost in time: A historical frame, elementary processing units and the 3-second window. Neurobiol Exp (Wars), 2004; 64(3), 295-302.

16. Szeląg E, Kowalska J. „Zegar” naszego mózgu a kształtowanie percepcji słuchowej. Kosmos, 1998; 47: 277-87.

17. Szeląg E. Mechanizmy percepcji czasu podstawą procesów świadomości. W: Jarymowicz M, Ohme RK, red. Natura automatyzmów: dyskusje interdyscyplinarne. Warszawa: Wydawnictwo Instytutu Psychologii; 2002, s. 57-66.

18. Szeląg E. Czy mózg potrzebuje „zegara”? Mechanizmy przeżywania czasu podstawą naszej świadomości. W: Sędek G, Bedyńska S, red. Życie na czas. Perspektywy badawcze postrzegania czasu. Warszawa: PWN; 2010, s. 189-230.

19. Pöppel E. Pre-semantically defined temporal windows for cognitive processing. Philos Trans R Soc Lond B Biol Sci, 2009; 364(1525): 1887-96.

20. Pöppel E, Logothetis N. Neuronal oscillations in the brain. Discontinuous initiations of pursuit eye movements indicate a $30-\mathrm{Hz}$ temporal framework for visual information processing. Naturwissenschaften, 1986; 73(5): 267-68.

21. Szymaszek A, Szeląg E, Śliwowska M. Auditory perception of temporal order in humans: the effect of age, gender, listener practice and stimulus presentation mode. Neurosci Lett, 2006; 403(1-2): 190-94.

22. Szymaszek A, Sereda M, Pöppel E, Szeląg E. Individual differences in the perception of temporal order: the effect of age and cognition. Cogn Neuropsychol, 2009; 26(2): 135-47.
23. Kiss M, Cristescu T, Fink M, Wittmann M. Auditory language comprehension of temporally reversed speech signals in native and non-native speakers. Acta Neurobiol Exp (Wars), 2008, 68(2): 204-13.

24. Szeląg E. Temporal integration of the brain as studied with the metronome paradigm. W: Atmanspacher H, Ruhnau E, red. Time, Temporality, Now. Berlin: Springer; 1997, s. 107-20.

25. Wittmann M, v. Steinbüchel N, Szeląg E. Hemispheric specialization for self-paced motor sequences. Brain Res Cogn Brain Res, 2001; 10(3): 341-44.

26. Karmarkar UR, Buonomano DV. Timing in the absence of clocks: encoding time in neural network states. Neuron, 2007; 53(3): 427-38.

27. Creelman CD. Human discrimination of auditory duration. J Acoust Soc Am, 1962; 34: 582-93.

28. Church RM. Properties of the internal clock. Ann N Y Acad Sci, 1984; 423: 566-82.

29. Treisman M. Temporal discrimination and the indifference interval: Implications for a model of the 'internal clock'. Psychological Monographs, 1963; 77: 1-31.

30. Wittmann M. Time perception and temporal processing levels of the brain. Chronobiol Int, 1999; 16(1): 17-32.

31. Rammsayer TH, Brandler S. Aspects of temporal information processing: a dimensional analysis. Psychol Res, 2004; 69(1-2): 115-23.

32. Ulrich R, Nitschke J, Rammsayer T. Crossmodal temporal discrimination: assessing the predictions of a general pacemaker-counter model. Percep Psychophys, 2006; 68(7): 1140-52.

33. Ortega L, Lopez F, Church RM. Modality and intermittency effects on time estimation. Behav Processes, 2009; 81(2): 270-73.

34. Stauffer CC, Haldemann J, Troche SJ, Rammsayer TH. Auditory and visual temporal sensitivity: Evidence for a hierarchical structure of modality-specific and modality-independent levels of temporal information processing. Psychol Res, 2012; 76(1): 20-31.

35. Buhusi CV, Meck WH. What makes us tick? Functional and neural mechanisms of interval timing. Nat Rev Neurosci, 2005; 6(10): 755-65.

36. Durstewitz D. Self-organizing neural integrator predicts interval times through climbing activity. J Neurosci, 2003; 23(12): 5342-53.

37. Reutimann J, Yakovlev V, Fusi S, Senn W. Climbing neuronal activity as an event based cortical representation of time. J Neurosci., 2004; 24(13): 3295-303.

38. Miall C. The storage of time intervals using oscillating neurons. Neural Comput., 1989; 1: 359-71.

39. Matell MS, Meck WH. Cortico-striatal circuits and interval timing: coincidence detection of oscillatory processes. Brain Res Cogn Brain Res, 2004; 21(2): 139-70.

40. van Rijn H, Gu BM, Meck WH. Dedicated clock/timing-circuit theories of time perception and timed performance. Adv Exp Med Biol, 2014; 829: 75-99.

41. Gu BM, van Rijn H, Meck WH. Oscillatory multiplexing of neural population codes for interval timing and working memory. Neurosci Biobehav Rev, 2015; 48: 160-85.

42. Lewandowska M, Piątkowska-Janko E, Bogorodzki P, Wolak T, Szeląg E. Changes in fMRI BOLD response to increasing and decreasing task difficulty during auditory perception of temporal order. Neurobiol Learn Mem, 2010; 94(3): 382-91. 
43. Rubia K, Smith A. The neural correlates of cognitive time management: A review. Acta Neurobiol Exp (Wars), 2004; 64(3): 329-40.

44. Coull JT, Davranche K, Nazarian B, Vidal F. Functional anatomy of timing differs for production versus prediction of time intervals. Neuropsychologia, 2013; 51(2): 309-19.

45. Coull JT, Cheng RK, Meck WH. Neuroanatomical and neurochemical substrates of timing. Neuropsychopharmacology, 2011; 36(1): 3-25.

46. Meck WH, Penney TB, Pouthas V. Cortico-striatal representation of time in animals and humans. Curr Opin Neurobiol, 2008; 18(2): 145-52.

47. Livesey AC, Wall MB, Smith AT. Time perception: manipulation of task difficulty dissociates clock functions from other cognitive demands. Neuropsychologia, 2007; 45(2): 321-23.

48. Pouthas V, George N, Poline JB, Pfeuty M, Vandemoorteele PF, Hugueville L i wsp. Neural network involved in time perception: an fMRI study comparing long and short interval estimation. Hum Brain Mapp, 2005; 25(4): 433-41.

49. Nenadic I, Gaser C, Volz HP, Rammsayer T, Häger F, Sauer H. Processing of temporal information and the basal ganglia: New evidence from fMRI. Exp Brain Res, 2003; 148(2): 238-46.

50. Jones CR, Jahanshahi M. The substantia nigra, the basal ganglia, dopamine and temporal processing. J Neural Transm Suppl, 2009; 73: 161-71.

51. Lewandowska M, Bekisz M, Szymaszek A, Wrobel A, Szelag E. Towards electrophysiological correlates of auditory perception of temporal order. Neurosci Lett, 2008; 437(2): 139-43.

52. Rammsayer TH. Differences in duration discrimination of filled and empty auditory intervals as a function of base duration. Atten Percept Psychophys., 2010; 72(6): 1591-600.

53. Bao Y, Fang Y, Yang T, Wang L, Szymaszek A, Szelag E. Auditory perception of temporal order: A comparison between tonal language speakers with and without non-tonal language experience. Acta Neurobiol Exp (Wars), 2014; 74(1): 98-103.

54. Bao Y, Szymaszek A, Wang X, Oron A, Pöppel E, Szelag E. Temporal order perception of auditory stimuli is selectively modified by tonal and non-tonal language environments. Cognition, 2013; 129(3): 579-85.
55. Fink M, Churan J, Wittmann M. Assessment of auditory temporal order thresholds - a comparison of different measurement procedures and the influence of age and gender. Restor Neurol Neurosci, 2005; 23: 1-16.

56. Birkett EE, Talcott JB. Interval timing in children: effects of auditory and visual pacing stimuli and relationships with reading and attention variables. PLoS One, 2012; 7(8): e42820.

57. Szelag E, Lewandowska M, Wolak T, Seniow J, Poniatowska R, Pöppel E i wsp. Training in rapid auditory processing ameliorates auditory comprehension in aphasic patients: A randomized controlled pilot study. J Neurol Sci, 2014; 338(1-2): 77-86.

58. Oron A, Szymaszek A, Szelag E. Temporal information processing as a basis for auditory comprehension: Clinical evidence from aphasic patients. Int J Lang Commun Disord, 2015; 50(5): 604-15.

59. Szeląg E, Szymaszek A. Nowe spojrzenie na zegar mózgowy: Test do badania rozumienia mowy u dzieci i dorosłych. Gdańsk: Gdańskie Wydawnictwo Psychologiczne; 2014.

60. Lisker L, Abramson AS. A cross-language study on voicing in initial stops. Acoustical measurements. Word, 1964; 20: 384-422.

61. Fogerty D, Humes LE, Kewley-Port D. Auditory temporal-order processing of vowel sequences by young and elderly listeners. J Acoust Soc Am, 2010; 127(4): 2509-20.

62. Kanabus M, Szelag E, Kolodziejczyk I, Szuchnik J. Reproduction of auditory and visual standards in monochannel cochlear implant users. Acta Neurobiol Exp (Wars), 2004; 64(3): 395-402.

63. Block RA, Zakay D. Prospective and retrospective duration judgments: A meta-analytic review. Psychon Bull Rev, 1997; 4(2): 184-97.

64. Szeląg E, von Steinbüchel N, Pöppel E. Temporal processing disorders in patients with Broca's aphasia. Neurosci Lett, 1997; 235(1-2): 33-36.

65. Zhou B, Pöppel E, Bao Y. In the jungle of time: the concept of identity as a way out. Front Psychol, 2014; 5: 844. 